\title{
INTENTION/REFLECTION (I/R) PRACTICE TO ENGAGE STUDENT LEADERS
}

\section{Abstract}

This mixed method study explores how a simple educational practice known as Intention/Reflection (I/R) may be applied to student leadership development to facilitate transformational learning. The study included Pharm.D. students within a leadership elective course $(n=242)$ across five years of courses (fall 2014 to fall 2018). Further research was conducted with students participating in two additional leadership courses, spring 2016 ( $n=24)$. These students completed a quantitative pre- and post-survey regarding perceptions of the $1 / R$ practice. A statistically significant increase was identified in the way students valued the $\mathrm{I} / \mathrm{R}$ practice in educational settings. Students reported the intention activity helped them focus their learning reflection on specific self-development goals. They also reported the I/R practice helped them identify, solidify, and track their leadership development needs. In addition to course content and leadership skills, students reported that the $\mathrm{I} / \mathrm{R}$ practice helped them learn about their own strengths, weaknesses, and needs as emerging leaders. The study also includes student perceptions of its utility as a tool in their professional growth. Furthermore, the $1 / R$ practice has the potential to provide a large source of information to help educators enhance their learning environments, by capturing student perceptions of the learning environment, and assessing how students are connecting learning activities and course material to their own development. This formative information can be useful as educators develop learning activities, assess developmental gains, and evaluate the effectiveness of their leadership instruction.

\section{Introduction}

Understanding student motivation can be a puzzling experience for many college teachers. The work of Carol Dweck, among many others, has helped demystify what can be a confusing and frustrating aspect of college teaching. Dweck identified two classes of goals common to students: performance goals, and learning goals (Dweck \& Leggett, 1988): findings which would later be developed into her work on mindset (2006). Simply put, Dweck's research revealed some students' tendencies to view a higher grade as more valuable or important than mastery of course content.

Related to this is research indicating that some students seem challenged by the prospect of reflective writing exercises. Specifically, some students seem to be naturally disinclined toward self-reflective thinking, or lack inherent reflective skills (Roberts \& Yoell, 2009, Grant, et al, 2002). Added to these is the reality that reflection is a broad topic, and expectations can be unclear for some students (Williams \& Wessel, 2004, Duckett, 2002). 
With the above research findings in mind, one could understand if some students might prefer a codified, quantifiable educational experience in which expectations are unambiguous, and success/failure is clearly defined. (The alternative being a challenging but subjective experience in which success/failure is not based on a clear right/wrong dichotomy.) Unpublished data supports this assertion: 50\% (+/1\%) of 510 incoming PharmD students surveyed across three years in one college of pharmacy responded they would rather receive a good grade than be challenged when learning course material.

The study of leadership, by contrast, is less concrete, and dependent more on the learner's unique attributes than on any external quantifiable course content (Lussier \& Achua, 2007). Which could mean, students in science programs may find leadership studies somewhat challenging due to their previous educational experiences. Learning abstract course content, such as leadership, can be a stretch goal in itself. Because of the qualitative nature of the topic, students must develop metacognitive skills to adapt to a new way of learning. The goal isn't to have students converge on the "right" answer, or be motivated by the reward of a grade. The goal is to have students explore a variety of divergent leadership perspectives, and develop intrinsic motivation based on their own unique strengths and objectives.

This phenomenon could be described as analogous to the difference between transactional and transformational leadership. Burns (1978) described transactional leadership as occurring when two parties exchange efforts. For instance, there is a reward for a behavior that creates a transaction in leadership style (e.g. transaction is the grade). Burns further explained that transformational leadership is when the leader engages the follower with a higher devoted motivation where both leader and follower "become fused" (p. 20). Another difference between transactional and transformational leadership is that "the transactional leader works within the framework of the self-interests of his or her constituency, whereas the transformational leader moves to change the framework" (Bass, 1990, p. 23). The student views personal understanding and development as equally as important as the course objectives. It is through transformational leadership that a follower will be transformed into a leader and adopt similar principles to create an outcome that is not self-serving. It is a style where followers are converted into leaders of their own (Bass).

Education models have used similar language to describe the classroom environment. Paavola and Hakkarainen (2005) describe differences between learning by acquisition, and learning by knowledge generation. Learning by acquisition can be represented by a traditional lecture-based, teachercentered course in which students are provided information and expected to know that material for the exam. An implicit exchange or transaction occurs in this teaching/learning paradigm: students are given a grade for memorizing a certain amount of information. Learning by knowledge generation, on the other hand, involves critical examinations of the thoughts, beliefs, and assumptions guiding our behaviors and decisions. In this model, students learn when they make meaning from, or interpret, their decisions and actions in a given social situation. This examination is foundational to a transformative experience for students (Mezirow, 1991).

Learning by both acquisition (quantitative) and by knowledge generation (qualitative) is similar to the scaffolding process of leadership development proposed by Katz (1974). There are three specific leadership skills Katz described: "Performing the technical activities (technical skill), understanding and motivating individuals and groups (human skill), and coordinating and integrating all the activities and interests of the organization toward a common objective (conceptual skill)" (p. 5). For instance, Katz (1974) mentioned that although each leader should have the three skills, they should be maximized 
differently depending on whether the leader is in top management, middle management, or supervisory management (Northouse, 2004). According to Northouse, within lower management levels, technical and human skills are most important. For middle managers, the three different skills are equally important. At upper management levels, conceptual and human skills are most important, while technical skills become less important. Leaders are more effective when there is a match between their skills and their management level (p. 62). This framework applies directly to the work of health care professionals; they must master technical skills, human skills, and conceptual skills to be effective health care providers and leaders in their organizations. Within the health profession field, reflection is an essential skill for physicians in practice (Uyger et al, 2019).

The development of these various levels of skills can be facilitated through reflection and reflective writing exercises (Schön, 1983). As mentioned above, students who have long been successful under traditional "acquisition" type classes may be challenged by self-reflective activities, simply because there are few (if any) clear right or wrong answers, which have been the traditional measuring sticks of success in science-based curricula (National Center for Education Statistics [NCES], 2002). Defining success or achievement when learning through knowledge generation, similar to learning transformational leadership, is much more difficult to quantify because the gains are more personal and unique to the individuals involved.

The result we are left to contend with as educators is some students seem to have developed learning habits and beliefs that are ineffective or inadequate when applied to the complexity and subjectivity of leadership education.

Intention/Reflection (I/R) in Leadership. Traits important within leadership development include having a solid vision and continual improvement on leadership skills through self-reflection. In order for leaders to be effective it is imperative to have a vision (Kouzes \& Posner, 1995). The purpose of a vision is it allows leaders to create a consistent identity to strive towards (Senge, 1990, 1994). This consistency is what can anchor students to achieve specific outcomes and allows them to reflect when they stray from their desired paths. It's what keeps leaders inspired to make changes throughout their work (Kouzes \& Posner, 2008). What is even more critical through this process of identification of a vision, is the continual self-evaluation to ensure that one is on target overall. This frequent pause to look back on experiences and outcomes, when immersed with an intentional focus becomes a powerful tool to help hone leadership skills and create continuous development for leaders.

With this in mind, a practice has been developed to encourage learner engagement by identifying and infusing students' personal interests and motivations into the learning outcomes identified by the teacher (Fierke \& Lepp, 2015). Prior to a given learning experience - course, activity, project, exercise, etc. - students articulate specifically what they expect to gain from the experience, and how they work to achieve that gain. This approach is based primarily on constructivist education theory, originated by Piaget (1961, 1969), and expanded upon by von Glasersfeld (1984) and others. After the learning experience, students reflect on the activity to help identify gains in knowledge or skill, and if their expectations matched the result. They also reflect on how they might approach future experiences differently to achieve a better result. This practice is called Intention/ Reflection (I/R) (Figure 1). The relatively low-intensity, no-tech nature of this practice allows it to be applied to almost any learning experience, and the simplicity allows learners to easily engage in it. When intentions (goals) are examined through a deliberate reflection process, students are able to "complete the loop" of their learning, which may facilitate metacognitive development, as noted below. 


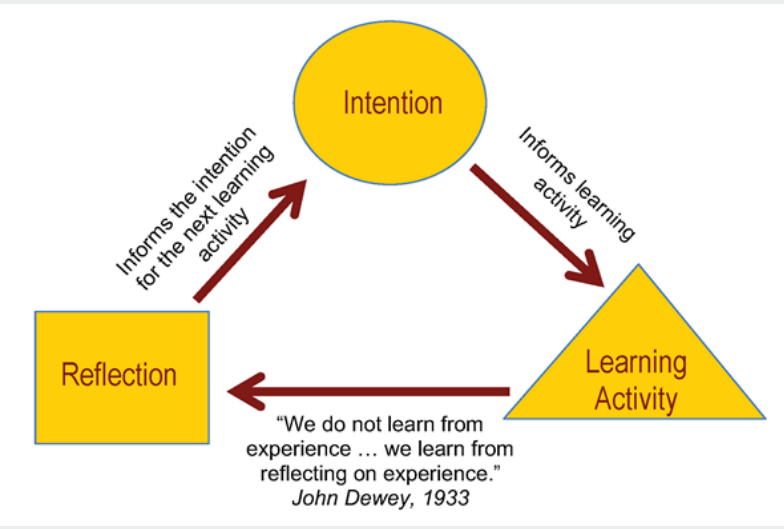

Figure 1. Intention/Reflection (I/R) Practice

\section{Methods}

The mixed methods study included Pharm.D. students $(n=242)$ in a leadership elective course in which active student participation was used for the bulk of the course. This course, Foundations of Leadership (FoL), is the first offered in a series of leadership electives (up to six) available for students to complete. This qualitative study was conducted with students across five years of courses (fall 2014 to fall 2018) a total of 242 students across two campuses in the same college participated. Further research was conducted with students participating in two additional leadership courses, spring 2016, on one campus $(n=24)$. These students completed a quantitative pre and post survey regarding perceptions of the $\mathrm{I} / \mathrm{R}$ practice. The purpose of $\mathrm{a}$ mixed-method approach provided greater depth and understanding of the student experience.

The final assignment of the FoL course is for students to complete a leadership self-assessment which includes the $\mathrm{I} / \mathrm{R}$ practice. The completed self-assessment provides an opportunity for students to identify specific areas of leadership they would like to further develop. It is intended to assist students in targeting future, individualized leadership development efforts. The leadership development self-assessment assignment is broken into three parts: 1) intention, 2) analyzing personal development, and 3) reflection. Each of the parts are completed by the student at different times, however they are due to the faculty at the same time. The intention is completed first. The purpose of which is for students to identify "why" personal development is important as well as some obstacles they may encounter during the completion of the assignment and ways to overcome these obstacles. Both the intention (step 1) and personal development (step 2) portions are brought to class on the designated date for further discussion and are incorporated into the class activities. The personal development portion consists of students reviewing all course materials and assessments throughout the semester and identifying areas they can further develop their leadership. After class, students complete the final reflection (step 3) and submit the entire assignment (all three parts). The reflection portion describes what they experienced during the completion of the assignment.

Evaluation of the $\mathrm{I} / \mathrm{R}$ included a qualitative analysis. 
Responses to two intention and two reflection qualitative questions were descriptively coded, then grouped into themes using N'Vivo, Version 11.4. Comments were coded and various themes were identified from the qualitative data (leadership development, leadership awareness, and leadership ability). The specific questions analyzed were intended to reveal the thought process of students specifically interested in leadership development. This includes the preparation steps of completing a leadership self-assessment as well as the outcome(s) of incorporating an I/R practice into the assignment.

A sample of students in spring 2016 from one campus, who completed the self-assessment (fall 2016; fall 2015) participated in a Likert scale survey to self-assess their perception of value and behavioral change (if any) associated with the I/R practice. The survey also included preparation for class questions and an open-comment asking students to describe how they have used the I/R process and whether it was valuable or not. These anonymous pre- and post-course surveys were administered to the students, and linked through personal unique identification statements. The quantitative pre-/post test perceptions data were analyzed further using a paired sample t-test after the completion of the courses.

\section{Results}

Leadership self-assessments were analyzed for 242 students across five semesters (fall 2014: 37 students; fall 2015: 40 students; fall 2016: 67 students; fall 2017: 36 students; fall 2018: 62 students). Two intention and two reflection questions were descriptively coded to capture the main thoughts(s) of each student's response. Codes were then grouped into broader ideas (themes) by question in order to identify major concepts. When warranted, a student's comment was broken out across multiple sub-themes/themes. While a student may be counted in more than one sub-theme/theme, he or she is only counted once within each sub-theme/theme (unduplicated count). Segmenting out each student's separate thought and viewing results at the unduplicated student level provides the proportional weight of each idea across all students. That is, within the results tables, percentages represent the quotient of students with a related response out of all students responding to the question.

Intention. The first question students were asked to answer was, "Why is leadership self-assessment important to you?" Of the 242 students, 230 provided responses to this question that could be coded (95.0\%). Responses broadly grouped into three themes: Leadership awareness, Leadership development, and Leadership ability (Table 1). Fortyeight percent of respondents indicated that the leadership self-assessment was important to them because they desired greater leadership awareness. Most commonly referred to was identifying areas of improvement (29.1\%) and strengths (20.4\%). Fourteen percent $(n=31)$ of respondents mentioned identifying both areas of improvement and strengths as being important. Within the area of Leadership development, respondents most frequently cited the importance of being able to identify their leadership progress, development, or growth (29.1\%), with one student writing, "Evaluation of personal development and the progression of social and strategic skill sets are an essential tool in the pursuit of personal growth." Another prominent topic, although to a lesser extent, was the desire to improve or develop their leadership skills (18.7\%). "I think that through gaining a better understanding [of] myself I will be able to make necessary changes to improve my leadership abilities," explained one student.

In addition to course content and leadership skills, students reported that the I/R practice helped them learn about their own strengths, weaknesses, and needs as emerging leaders:

"The intention/reflection activity ... helped me think about my strengths and weaknesses going forward." 


\begin{tabular}{|c|c|c|}
\hline Theme Sub-Theme & Example & Frequency \\
\hline Leadership awareness & & $111(48.3 \%)$ \\
\hline $\begin{array}{l}\text { To identify areas of } \\
\text { improvement }\end{array}$ & $\begin{array}{l}\text { "Leadership development self-assessment is } \\
\text { important because it provides an opportunity for } \\
\text { me to invest time in identifying areas that I need to } \\
\text { improve on" }\end{array}$ & $67(29.1 \%)$ \\
\hline To identify strengths & $\begin{array}{l}\text { "Leadership development self-assessments are } \\
\text { important to me, because they allow me to learn } \\
\text { my strengths as a leader" }\end{array}$ & $47(20.4 \%)$ \\
\hline $\begin{array}{l}\text { Shows me where I'm } \\
\text { at, where I should be }\end{array}$ & $\begin{array}{l}\text { "This self-assessment is important to me because it } \\
\text { doesn't tell me what I should be doing, but instead it } \\
\text { shows me where l'm at." }\end{array}$ & $21(9.1 \%)$ \\
\hline $\begin{array}{l}\text { Allows me to learn more } \\
\text { about who I am, my } \\
\text { passions, motivations }\end{array}$ & $\begin{array}{l}\text { "The leadership development self-assessment is } \\
\text { important to me, because I want to learn more } \\
\text { about what my passion is and where it will take } \\
\text { me." }\end{array}$ & $16(7.0 \%)$ \\
\hline Leadership development & & $95(41.3 \%)$ \\
\hline $\begin{array}{l}\text { To identify progress, } \\
\text { development, growth }\end{array}$ & $\begin{array}{l}\text { "Leadership development self-assessment is } \\
\text { important because it allows you to step back and } \\
\text { look at the progress you have made..." }\end{array}$ & $67(29.1 \%)$ \\
\hline $\begin{array}{l}\text { To identify what I have } \\
\text { learned, experienced }\end{array}$ & $\begin{array}{l}\text { "A leadership development self assessment is } \\
\text { important for reflecting on what I learned this } \\
\text { semester" }\end{array}$ & $22(9.6 \%)$ \\
\hline $\begin{array}{l}\text { Allows me to create a } \\
\text { leadership plan }\end{array}$ & $\begin{array}{l}\text { "A leadership development self-assessment is } \\
\text { important to me because it will help me lay out a } \\
\text { solid plan for what I want to do and what I want to } \\
\text { gain from my leadership experiences..." }\end{array}$ & $11(4.8 \%)$ \\
\hline Leadership ability & & $83(36.1 \%)$ \\
\hline $\begin{array}{l}\text { To improve, develop } \\
\text { leadership skills }\end{array}$ & $\begin{array}{l}\text { "A leadership development self-assessment is } \\
\text { important to me because I want to continue to build } \\
\text { as a leader." }\end{array}$ & $43(18.7 \%)$ \\
\hline $\begin{array}{l}\text { Want to be a } \\
\text { successful, effective } \\
\text { leader }\end{array}$ & $\begin{array}{l}\text { "Leadership development self-assessment is } \\
\text { important to me because it will help me to become } \\
\text { a more effective leader." }\end{array}$ & $27(11.7 \%)$ \\
\hline \multirow[t]{2}{*}{$\begin{array}{l}\text { To learn how, where to } \\
\text { apply leadership skills }\end{array}$} & $\begin{array}{l}\text { "It is very important for me as because it can guide } \\
\text { myself to implement my strength and put them into } \\
\text { real life application." }\end{array}$ & $17(7.4 \%)$ \\
\hline & Total \# students responding & 230 \\
\hline
\end{tabular}

percentages may exceed 100\%. Percentages reflect the proportion of the total number of students responding with comments related to a particular theme/sub-theme. Also, not all sub-themes may be listed in the table, due to space constraints.

Table 2 displays the thematic analysis for the question, "What do you hope to gain or learn from this experience?" Eighty-four percent (204/242) of students provided answers that could be coded. Leadership awareness, Leadership ability, and Leadership development again emerged as the main themes. Topics related to Leadership awareness were the most commonly referenced by students (57.4\%), with 34 percent of respondents hoping to identify areas of improvement. One student wrote, "From this experience I hope to gain the knowledge of accurate self-perception so that I may know which aspects I need to work harder on to develop in order to become an effective leader." Nearly 50 percent of respondents mentioned that they hope to gain or learn something pertaining to their leadership ability. More specifically, was the desire to learn how to improve or develop their existing leadership skills (21.1\%) and learn new leadership skills (11.8\%). Leadership development was touched on by 39 percent of respondents, with the most frequently cited sentiment being the desire to identify progress and growth. One student explained, "While it would be awesome to conclude that I have grown exponentially in terms of my leadership skills and am ready to go out into the real world, I know that this is not the case. I am also honestly unaware if I have incorporated any of the covered material into my leadership portfolio, so to be able to get an honest report that will mark my progress will be beneficial." 
Table 2

Responses to question: "What do you hope to gain or learn from this experience?"

\begin{tabular}{|c|c|c|}
\hline Theme Sub-Theme & Example & Frequency \\
\hline Leadership awareness & & $117(57.4 \%)$ \\
\hline $\begin{array}{l}\text { To identify areas of } \\
\text { improvement }\end{array}$ & $\begin{array}{l}\text { "I hope to gain some insight into what I need to } \\
\text { improve on to improve my leadership abilities." }\end{array}$ & $69(33.8 \%)$ \\
\hline To identify strengths & $\begin{array}{l}\text { "... will be able to find what I am doing well in order } \\
\text { to continue to practice those characteristics." }\end{array}$ & $27(13.2 \%)$ \\
\hline $\begin{array}{l}\text { Greater self- } \\
\text { awareness, } \\
\text { understanding }\end{array}$ & $\begin{array}{l}\text { "I hope to gain a more realistic, honest, and helpful } \\
\text { view of myself..." }\end{array}$ & $26(12.7 \%)$ \\
\hline $\begin{array}{l}\text { Better understanding } \\
\text { of leadership abilities, } \\
\text { strengths }\end{array}$ & $\begin{array}{l}\text { "From this, I hope to learn where I am currently at } \\
\text { with my leadership skills..." }\end{array}$ & $19(9.3 \%)$ \\
\hline Leadership skills & & $96(47.1 \%)$ \\
\hline $\begin{array}{l}\text { How to improve, } \\
\text { develop existing skills }\end{array}$ & $\begin{array}{l}\text { "I hope to learn how I can improve my leadership } \\
\text { skills..." }\end{array}$ & $43(21.1 \%)$ \\
\hline New leadership skills & $\begin{array}{l}\text { "I hope to gain good leadership skills from this } \\
\text { class..." }\end{array}$ & $24(11.8 \%)$ \\
\hline $\begin{array}{l}\text { How to apply leadership } \\
\text { skills }\end{array}$ & $\begin{array}{l}\text { "After finding these areas, I hope to be able to } \\
\text { identify specific ways in which I can practice these } \\
\text { areas." }\end{array}$ & $23(11.3 \%)$ \\
\hline More confidence & $\begin{array}{l}\text { "... hope to gain self-confidence in my leadership } \\
\text { abilities" }\end{array}$ & $19(9.3 \%)$ \\
\hline Leadership development & & $80(39.2 \%)$ \\
\hline $\begin{array}{l}\text { Ability to identify } \\
\text { progress, growth }\end{array}$ & $\begin{array}{l}\text { "This self-assessment will help me gauge on how } \\
\text { much I have grown..." }\end{array}$ & $34(16.7 \%)$ \\
\hline $\begin{array}{l}\text { Ability to identify what } \\
\text { I have learned }\end{array}$ & $\begin{array}{l}\text { "I'm hoping to reflect on what l've learned this year } \\
\text { in order to better apply it." }\end{array}$ & $17(8.3 \%)$ \\
\hline $\begin{array}{l}\text { Ability to reflect, self- } \\
\text { assess }\end{array}$ & $\begin{array}{l}\text { "Through this course and this assignment, } 1 \text { hope to } \\
\text { gain insight into how best to reflect on my } \\
\text { leadership." }\end{array}$ & $17(8.3 \%)$ \\
\hline $\begin{array}{l}\text { A leadership plan, } \\
\text { direction }\end{array}$ & $\begin{array}{l}\text { "...that it will allow me to actually create a plan to } \\
\text { improve." }\end{array}$ & $12(5.9 \%)$ \\
\hline
\end{tabular}

Note: Student responses may include separate comments that fit into more than one the me/sub-theme, so the sum of percentages may exceed 100\%. Percentages reflect the proportion of the total number of students responding with

comments related to a particular theme/sub-theme. Also not all sub-themes may be listed in the table, due to space

constraints.

Reflection. At the reflection stage, students were first asked if the leadership development self-assessment experience provide what they expected. Seventy-five percent of the students responded to this question $(181 / 242)$. More than 80 percent of students responding to the question said it did provide what they expected ( $n=149$ ), with one student writing, "The leadership development self-assessment experience did provide what I expected. I was able to reflect upon my development as a leader and consider what really inspires me to be a leader." Eleven percent of respondents said the self-assessment was somewhat what they were expecting, with the remaining respondents saying the leadership development selfassessment experience did not provide what they were expecting. One student wrote, "Through the leadership assessment, I actually learned more about myself rather than my leadership style. Despite the difference in expectation, I found it valuable because it reminds me of my motivation, passion, and vision."

As a follow-up question, students were asked if anything surprised them during the self-assessment process, and if so, what (Table 3). Approximately 70 percent of students $(n=177)$ indicated whether something during the self-assessment process surprised them, 25 of which (14.1\%) said nothing surprised them. Responses of those who were surprised by something were quite disperse, with 40 percent of respondents indicating they were surprised by a Self-discovery and 32 percent surprised by something related to the Leadership material. The remainder of responses was related to their Peers and the Self-assessment activities. Only one sub-theme garnered more than 10 percent of respondents: the ability to retain material, think of 
examples. In addition to students' surprise at their retention of the material, several of the more common sentiments shared by students was discovering their barriers/areas for improvement, the breadth of information covered, and the similarities between themselves and their peers. One student expressed, "What surprised me is that many people agreed with me on how difficult it can be to express your opinions even when you think you have good ideas."

The last reflection question for leadership selfassessment activity was "Considering the entire Intention/Reflection activity, how has it been helpful in enhancing your experience?" Two-hundred and thirteen students responded to the question, but approximately 40 percent $(n=89)$ of the students focused exclusively on the self-assessment activity instead of Intention/ Reflection. Comments from the students who responded through the lens of Intention/Reflection (124/213) grouped into four main themes: leadership development, learning, mindset, and self-discovery (Table 4). Leadership development and learning emerged as the most prominent themes, with 45 percent of students having a related comment to each.

Table 3

Responses to question: "What surprised you during this process?"

\begin{tabular}{|c|c|c|}
\hline $\begin{array}{l}\text { Theme Sub-Theme } \\
\text { Self-discovery }\end{array}$ & Example & $\begin{array}{l}\text { Frequency } \\
71(40.1 \%)\end{array}$ \\
\hline $\begin{array}{l}\text { Ability to retain material, } \\
\text { think of examples }\end{array}$ & $\begin{array}{l}\text { "The thing that surprised me was how much I } \\
\text { remembered some topics, and how much I had to } \\
\text { look up or ask about to refresh my memory." }\end{array}$ & $18(10.2 \%)$ \\
\hline $\begin{array}{l}\text { Discovering my barriers, } \\
\text { areas of improvement }\end{array}$ & $\begin{array}{l}\text { "One of these surprises is that I found that my } \\
\text { weaknesses did not lie as much with my own } \\
\text { motivation or work, but with the need to relate to } \\
\text { others." }\end{array}$ & $16(9.0 \%)$ \\
\hline $\begin{array}{l}\text { Already implementing } \\
\text { leadership concepts }\end{array}$ & $\begin{array}{l}\text { "I was surprised with how I already do some of } \\
\text { these leadership concepts without knowing it." }\end{array}$ & $10(5.6 \%)$ \\
\hline Personal reflection & $\begin{array}{l}\text { "What surprised me is just how little I had thought } \\
\text { about real life applications before this assessment." }\end{array}$ & $10(5.6 \%)$ \\
\hline Leadership material & & $56(31.6 \%)$ \\
\hline $\begin{array}{l}\text { Breadth, of } \\
\text { information covered in } \\
\text { course }\end{array}$ & $\begin{array}{l}\text { "I was surprised by the great deal of material we } \\
\text { covered." }\end{array}$ & $16(9.0 \%)$ \\
\hline Applicability of material & $\begin{array}{l}\text { "I found it surprising that once I reflected on each of } \\
\text { the leadership concepts, I could see how each could } \\
\text { be applied in someway." }\end{array}$ & $13(7.3 \%)$ \\
\hline $\begin{array}{l}\text { How much I learned, } \\
\text { took away }\end{array}$ & $\begin{array}{l}\text { "I think I was most surprised by how much I actually } \\
\text { took away from the content..." }\end{array}$ & $11(6.2 \%)$ \\
\hline Peers & & $27(15.3 \%)$ \\
\hline Similarities & $\begin{array}{l}\text { "One thing that I was surprised was the similarity } \\
\text { between my classmates and I." }\end{array}$ & $16(9.0 \%)$ \\
\hline Feedback & $\begin{array}{l}\text { "...I was surprised by some of the feedback I } \\
\text { received from my peers." }\end{array}$ & $5(2.8 \%)$ \\
\hline Differences & $\begin{array}{l}\text { "I felt that I had completely different expectations } \\
\text { for being a leader." }\end{array}$ & $3(1.7 \%)$ \\
\hline $\begin{array}{l}\text { Nothing was surprising } \\
\text { Self-assessment activities }\end{array}$ & & $\begin{array}{l}25(14.1 \%) \\
15(8.5 \%)\end{array}$ \\
\hline $\begin{array}{l}\text { Accuracy of personal } \\
\text { self-assessment }\end{array}$ & $\begin{array}{l}\text { "I was also surprise[d] at how accurate my analysis } \\
\text { of my self-assessment was when I discussed this } \\
\text { assignment with my husband." }\end{array}$ & $6(3.4 \%)$ \\
\hline Process & $\begin{array}{l}\text { "However, the process and the outcome of the } \\
\text { session surprised me." }\end{array}$ & $4(2.3 \%)$ \\
\hline \multirow[t]{2}{*}{$\begin{array}{l}\text { How helpful discussion } \\
\text { was }\end{array}$} & $\begin{array}{l}\text { "I was also surprised how helpful it was to talk } \\
\text { about our self-assessments in class today." }\end{array}$ & $3(1.7 \%)$ \\
\hline & Total \# students responding & 177 \\
\hline
\end{tabular}


Related to leadership development, the most frequently cited topics were that I/R helped them identify their goals and helped them identify or track their progress or growth (13.7\%). One student explained, "This entire activity helped me to look back and look forward about my leadership path. And provide me a more clearly direction that I would like to pursue for my future leadership development goal."

Within the learning theme, students most commonly indicated that I/R helped them see what they learned/ experienced (17.7\%) and that it helped solidify and contextualize content (16.1\%). Some students mentioned that Intention/Reflection enhanced their educational gains as well. As one student reflected, "I think that the intension and reflection portion of this activity helped make the self-assessment process more meaningful and thoughtful than if these steps had not occurred."

A sizable number of students also indicated that $I / R$ helped enhance their experience by affecting their mindset (40.3\%). Specifically, students reported that it framed their mindset, encouraged them to think more critically, and increased their awareness. One student wrote, "By stating my intentions before writing about my leadership, I put myself in a different mindset, where I wasn't just thinking about finishing the paper, but I was striving to pull something out of it that could help in the future."

Table 4

Responses to question: "How has it been helpful in enhancing your experience?"

\begin{tabular}{|c|c|c|}
\hline \multirow{2}{*}{\multicolumn{2}{|c|}{$\begin{array}{l}\text { Theme Sub-Theme Example } \\
\text { Leadership development }\end{array}$}} & \multirow{2}{*}{$\begin{array}{l}\text { Frequency } \\
56(45.2 \%)\end{array}$} \\
\hline & & \\
\hline $\begin{array}{l}\text { Identified, clarified } \\
\text { goals or direction }\end{array}$ & $\begin{array}{l}\text { "...I think the intention portion was a good way of goal } \\
\text { setting before completing the self-assessment, and the } \\
\text { reflection now is a good way of checking off the goals that } \\
\text { were met.... }\end{array}$ & $17(13.7 \%)$ \\
\hline $\begin{array}{l}\text { Identified, tracked } \\
\text { progress, growth }\end{array}$ & $\begin{array}{l}\text { "...I was hit with a realization that stating intentions, } \\
\text { analyzing my leadership development, then reflecting on } \\
\text { the process is what I really need in declaring and } \\
\text { solidifying my leadership development." }\end{array}$ & $17(13.7 \%)$ \\
\hline $\begin{array}{l}\text { Learned how, where } \\
\text { to apply skills }\end{array}$ & $\begin{array}{l}\text { "... has given me the opportunity to take an in depth look } \\
\text { at the concepts we've covered and how I can apply them } \\
\text { to my life as a student and in the future as a pharmacist." }\end{array}$ & $13(10.5 \%)$ \\
\hline Learning & & $56(45.2 \%)$ \\
\hline $\begin{array}{l}\text { Saw what I learned, } \\
\text { experienced }\end{array}$ & $\begin{array}{l}\text { "The entire Intention/Reflection activity has been helpful in } \\
\text { helping me realize how much I have learned." }\end{array}$ & $22(17.7 \%)$ \\
\hline $\begin{array}{l}\text { Solidified, } \\
\text { contextualized } \\
\text { content }\end{array}$ & $\begin{array}{l}\text { "By going through each lesson, it has served to tie each } \\
\text { one together and create a good summary of each lesson } \\
\text { and how each one has impacted me..." }\end{array}$ & $20(16.1 \%)$ \\
\hline $\begin{array}{l}\text { Enhanced } \\
\text { educational gains }\end{array}$ & $\begin{array}{l}\text { "The act of purposefully focusing on learning objectives } \\
\text { before, during, and after an activity or experience really } \\
\text { enhances the educational gains made by participating in } \\
\text { the activity..." }\end{array}$ & $10(8.1 \%)$ \\
\hline Mindset & & $50(40.3 \%)$ \\
\hline Framed my mindset & $\begin{array}{l}\text { "Establishing the goals of the reflection before doing it was } \\
\text { helpful in framing how I want to work on myself." }\end{array}$ & $19(15.3 \%)$ \\
\hline $\begin{array}{l}\text { Made me think } \\
\text { more critically }\end{array}$ & $\begin{array}{l}\text { "The whole Intention/Reflection activity has challenged } \\
\text { me to critically think about how this process influences } \\
\text { me as an individual." }\end{array}$ & $15(12.1 \%)$ \\
\hline Increased awareness & $\begin{array}{l}\text { "... really helped enhance my experience by allowing me to } \\
\text { be more self-aware of my level in self-growth and } \\
\text { leadership combined." }\end{array}$ & $11(8.9 \%)$ \\
\hline Self-discovery & & $14(11.3 \%)$ \\
\hline $\begin{array}{l}\text { Identified strengths } \\
\text { and areas of } \\
\text { improvement }\end{array}$ & $\begin{array}{l}\text { "The intention/reflection activity was beneficial in } \\
\text { enhancing my experience, because it helped make me } \\
\text { think about my strengths and weaknesses going forward. }\end{array}$ & $16(12.9 \%)$ \\
\hline $\begin{array}{l}\text { Identified, solidified, } \\
\text { my intentions, values }\end{array}$ & $\begin{array}{l}\text { "The self-assessment process has really helped reflect and } \\
\text { gain focus towards my "why", passion, and vision." }\end{array}$ & $5(4.0 \%)$ \\
\hline $\begin{array}{l}\text { Identified barriers, } \\
\text { obstacles }\end{array}$ & $\begin{array}{l}\text { "... the intention activity was extremely helpful, specifically } \\
\text { identifying barriers/obstacles." }\end{array}$ & $4(3.2 \%)$ \\
\hline & Total \# students responding & 124 \\
\hline
\end{tabular}


Quantitative Analysis. A subset of students $(n=24)$ participated in a survey to investigate the difference in pre-/post test perceptions and use of I/R. A paired sample t-test was used to compare the pre-/post test results, which are depicted in Table 5. The questions were meant to assess how much value students place on the $\mathrm{I} / \mathrm{R}$ practice, and how often they used the I/R practice. During the pre-test, students placed a significantly lower value on identifying what they hope to learn/gain from a class session before it begins $(M=3.13, S D=0.95)$ than the post-test $(M=$ 3.83, SD =0.70), $\mathrm{t}(23)=-3.09, \mathrm{p}=.005[-1.18,-0.23]$, with a medium effect size $(d=-0.64)$. In line with the change in value, the frequency in which students identified what they hoped to learn/gain from a class session before it began increased from the pre-test $(\mathrm{M}=2.13, \mathrm{SD}=0.85)$ to the post-test $(\mathrm{M}=2.83, \mathrm{SD}=$
0.64), $\mathrm{t}(23)=-5.03, \mathrm{p}<.001[-1.00,-0.42]$, with a large effect size $(d=-1.05)$.

When rating the item, "how valuable is preparing for a class session by completing pre-work and/or looking over a description of the session," students' scores were significantly higher in the post test $(M=$ $3.58, S D=0.83)$ than the pre-test $(M=3.08, S D=0.72)$, $t(23)=-2.63, p=.015[-0.89,-0.11]$, with an effect size of -0.54 . The mean score difference in mental preparedness at the start of each class session also showed an increase from the pre $(M=2.75, S D=0.90)$ to the post-test $(M=3.13, S D=0.80), t(23)=-2.84, p=$ $.009[-0.65,-0.10]$, with an effect size of -0.59 .

Table 5

Intention/Reflection Pre-Post Test Comparison

\begin{tabular}{|c|c|c|c|c|c|c|c|}
\hline \multirow[b]{2}{*}{ Variable } & \multicolumn{2}{|c|}{ Pre-test } & \multicolumn{2}{|c|}{ Post-test } & \multirow[t]{2}{*}{$t(23)$} & \multirow[t]{2}{*}{$p$} & \multirow{2}{*}{$\begin{array}{c}\text { Cohen's } \\
d\end{array}$} \\
\hline & $M$ & $S D$ & $M$ & $S D$ & & & \\
\hline $\begin{array}{l}\text { A. How valuable is identifying what you hope } \\
\text { to learn/gain from a class session before it } \\
\text { begins }\end{array}$ & 3.13 & 0.95 & 3.83 & 0.70 & -3.09 & $.005^{* *}$ & -0.64 \\
\hline $\begin{array}{l}\text { B. How valuable is preparing for a class } \\
\text { session by completing pre-work and/or } \\
\text { looking over a description of the session }\end{array}$ & 3.08 & 0.72 & 3.58 & 0.83 & -2.63 & $.015^{*}$ & -0.54 \\
\hline $\begin{array}{l}\text { C. How valuable is considering how content } \\
\text { in a class session connects with your future } \\
\text { pharmacy practice }\end{array}$ & 4.21 & 0.72 & 4.25 & 0.53 & -0.25 & .802 & -0.05 \\
\hline $\begin{array}{l}\text { D. How valuable is, after a class session, } \\
\text { asking critical questions (to yourself or } \\
\text { others) to deepen your level of } \\
\text { understanding of the things you learned }\end{array}$ & 4.00 & 0.83 & 4.04 & 0.62 & -0.20 & .840 & -0.04 \\
\hline $\begin{array}{l}\text { E. How valuable is thinking about the most } \\
\text { important points from a class session after it } \\
\text { is over }\end{array}$ & 4.13 & 0.68 & 4.04 & 0.62 & 0.46 & .647 & 0.10 \\
\hline $\begin{array}{l}\text { A. How frequently do you identify what you } \\
\text { hope to learn/gain from a class session } \\
\text { before it begins }\end{array}$ & 2.13 & 0.85 & 2.83 & 0.64 & -5.03 & $.000^{* * *}$ & -1.05 \\
\hline $\begin{array}{l}\text { B. How frequently do you prepare for a class } \\
\text { session by completing pre-work and/or } \\
\text { looking over a description of the session }\end{array}$ & 3.08 & 1.25 & 3.42 & 0.93 & -1.62 & .119 & -0.35 \\
\hline $\begin{array}{l}\text { How frequently do you consider how content } \\
\text { in a class session connects with your future } \\
\text { pharmacy practice }\end{array}$ & 3.88 & 0.95 & 4.00 & 0.83 & -0.62 & .543 & -0.12 \\
\hline $\begin{array}{l}\text { D. How frequently do you, after a class } \\
\text { session, ask critical questions (to yourself or } \\
\text { others) to deepen your level of } \\
\text { understanding of the things you learned }\end{array}$ & 2.96 & 1.08 & 3.13 & 0.95 & -0.81 & .426 & -0.17 \\
\hline $\begin{array}{l}\text { E. How frequently do you think about the } \\
\text { most important points from a class session } \\
\text { after it is over }\end{array}$ & 3.04 & 0.95 & 3.38 & 0.82 & -1.45 & .162 & -0.30 \\
\hline $\begin{array}{l}\text { On average, in your PharmD courses, how } \\
\text { mentally prepared are you at the start of } \\
\text { each class session? }\end{array}$ & 2.75 & 0.90 & 3.13 & 0.80 & -2.84 & $.009 * *$ & -0.59 \\
\hline 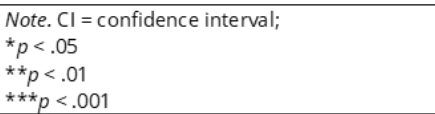 & & & & & & & \\
\hline
\end{tabular}


Student responses to the open-ended question, "describe how you have used the IR process and whether it was valuable or not," were descriptively coded. Results are displayed in Table 6. A little more than 40 percent of students outright said the IR process is valuable, with several implementing the practice outside of the classroom. Students reported using both intention and reflection, with nearly 40 percent of students mentioning they use intention to prepare their mindset, and 25 percent indicating they use reflection to assess if they have accomplished the objectives.

Table 6

Responses to question: "Describe how you have used the IR process and whether it was valuable or not."

\begin{tabular}{|c|c|c|}
\hline Theme Sub-Theme & Example & Frequenc \\
\hline Using IR & & $19(79.2 \%)$ \\
\hline Valuable & $\begin{array}{l}\text { "It is one of the most valuable takeaways from the LEA } \\
\text { class. I feel like it applies to all aspects regarding } \\
\text { interactions in my life." }\end{array}$ & $10(41.7$ \\
\hline Prepares my mindset & $\begin{array}{l}\text { "Intention helped me to get a certain mindset to go into } \\
\text { a class or situation with a goal" }\end{array}$ & $9(37.5$ \\
\hline $\begin{array}{l}\text { Assess if objectives } \\
\text { were accomplished }\end{array}$ & $\begin{array}{l}\text { "I will look at objectives before and after classes and } \\
\text { think if I accomplished them" }\end{array}$ & $6(25.0$ \\
\hline $\begin{array}{l}\text { Need to know content } \\
\text { of class for intention }\end{array}$ & $\begin{array}{l}\text { "Sometimes I find it hard to have that intention when } \\
\text { it's not really clear what is going on that day." }\end{array}$ & $2(8.3$ \\
\hline Where IR is used & & $5(20.8 \%)$ \\
\hline Meetings & $\begin{array}{l}\text { "Using it to start a meeting is very helpful to help the } \\
\text { participants stay focused on the main topic." }\end{array}$ & $2(8.3$ \\
\hline Class & "Before some classes, it depends on the subject" & $2(4.2$ \\
\hline $\begin{array}{l}\text { Reading books outside } \\
\text { of class }\end{array}$ & $\begin{array}{l}\text { "I feel like I haven't used it a lot for classes, but have } \\
\text { used it when reading books outside of class." }\end{array}$ & $1(4.2$ \\
\hline Frequency of IR & & $4(16.7 \%)$ \\
\hline $\begin{array}{l}\text { Forget to do on my } \\
\text { own }\end{array}$ & $\begin{array}{l}\text { "Many times I would forget just because it is not } \\
\text { something that you just think of doing naturally." }\end{array}$ & $3(12.5$ \\
\hline \multirow[t]{2}{*}{ Use more often now } & "More often now." & $1(4.2$ \\
\hline & Total \# students & 24 \\
\hline
\end{tabular}

\section{Discussion}

The data from this research study yields some interesting findings related to student behavior, which might be of assistance to educators seeking to craft engaging and meaningful learning experiences for students. These findings can be categorized under three broad headings: values vs. behaviors, individualized learning and metacognition, and value to educators.

Values vs. behaviors. A theme emerging from Tables 4-6 is students appear to value what they've gained from the I/R practice. These gains take several forms. For example, students reported the intention activity helped them focus their learning reflection on specific self-development goals:

"Establishing the goals of the reflection before doing it was helpful in framing how I want to work on myself."

Some students reported the I/R practice helped them identify, solidify, and track their leadership development needs:

"...I was hit with a realization that stating intentions, analyzing my leadership development, then reflecting on the process is what I really need in declaring and solidifying my leadership development." 
Additionally, Table 5 indicates students place a relatively high value on activities associated with preparation (intention) and reflection. Conversely, Table 5 also indicates students' propensity to engage in I/R on their own, outside of a class-mandated activity, is sporadic. Table 6 reinforces the finding that some students, even while believing it is valuable, don't fully engaged in the I/R practice on their own, or do so sporadically for certain occasions. Table 6 is useful not necessarily for assessing how many students use $\mathrm{I} / \mathrm{R}$, but for understanding how they are using it. Of those responding, the most compelling sub-theme may be from those students who use I/R to help prepare their cognitive state prior to a learning experience:

"The intention process makes me take time to consciously reflect on what I want to get out of an activity, which causes me to be more purposeful when completing the activity."

Also, despite having the largest increase between pretest and post-test, the lowest median score in Table 5 indicates students simply don't formally engage in I/R if it's not part of a class activity, despite seeing the value in it. This incongruity between value and use could be due to students attempting to engage in the I/R practice more efficiently by doing so informally, without writing down intention statements and reflection responses. Another possibility is students lack the skills to "monitor and control their own learning" - the two primary aspects of metacognition (Zimmerman, 2001). As a result, students haven't developed the cognitive habit of directing their own learning.

Individualized learning and metacognition. When asked how the I/R practice has been helpful (Table 4), the spectrum of student responses ranged across four themes and 17 sub-themes. The sub-theme mentioned most was only mentioned in $17.7 \%$ of the responses, while eight of the 17 sub-themes were mentioned in over $10 \%$ of responses. In other words, a significant number of students reported finding value in the I/R practice for many different reasons. The sheer volume of, variety within, and balance across sub-themes indicates this practice has the capacity to be valuable to a broad array of learners, who may bring unique needs and interests to the learning environment.

Tables 3 and 4 also highlight metacognitive development in at least some students in this study. Student responses to questions asking about the value of the I/R practice include: surprise at recognizing the breadth of material covered; connections between course content and professional practice; understanding of one's specific stage of leadership knowledge and skill; confidence in leadership skill development; self-awareness of educational interests, strengths and weaknesses; awareness of one's own learning arc, and more. These concepts are all connected to metacognition, which is a valuable skill for lifelong, self-directed learning (Ambrose et al, 2010).

Ultimately, the I/R practice appears to help at least some students identify specific educational aims or interests before a learning experience and facilitate meaningful reflection of those aims after the learning experience. As one student commented, "It is one of the most valuable takeaways from the [leadership] class. I feel like it applies to all aspects regarding interactions in my life."

Value to educators. This study is focused on student responses to the $\mathrm{I} / \mathrm{R}$ practice, and student perceptions of its utility as a tool in their professional growth. The data also reveal that the I/R has the potential to provide a large source of information to help educators enhance their learning environments. Tables 1-3 highlight that students study leadership from a variety of perspectives (personally, professionally, culturally, etc.), have a broad spectrum of existing knowledge and skills, and also bring a unique set of interests and educational goals to any learning environment. The I/R practice can help educators capture student perceptions of the learning environment, and assess how students are connecting learning activities and course material to their own development.

This formative information can be useful as educators develop learning activities, assess developmental 
gains, and evaluate the effectiveness of their leadership instruction.

\section{Conclusion}

Unlike health professions education, advanced leadership education requires students begin not by memorizing foundational information, but with a critical self-examination of their values, beliefs, biases, attitudes, interests, behaviors, etc. Only when students understand themselves are they able to effectively craft a vision and inspire others to join.

Leadership educators can encourage this selfexamination by using the $\mathrm{I} / \mathrm{R}$ practice, which helps students identify their unique interests, motivation, and learning intentions before a learning activity, and then reflect on those intentions after the activity. The results of this study suggest students who engage in the $I / R$ practice can experience metacognitive gains, which allows them to be more effective self-directed learners. Just as leadership studies teach students to have a strategic vision for the future and encourage a planful approach to achieving that vision, so does the $\mathrm{I} / \mathrm{R}$ practice encourage students to have a strategic vision of why and how they learn, which can help enhance lifelong leadership development. 


\section{References}

Ambrose, S. A., Bridges, M.W., DiPietro M, Lovett M.C., \& Norman, M.K. How Learning Works: 7 ResearchBased Principles for Smart Teaching. San Francisco: John Wiley \& Sons, Inc.; 2010.

Dewey, J. (1933). How we think (Revised). Boston: D.C. Heath.

Dweck, C. S. \& Leggett, E. L. (1988). A social-cognitive approach to motivation and personality. Psychological Review, (95)2, 256-273.

Dweck, C. S. (2006). Mindset: The new psychology of success. New York : Penguin Random House.

Duckett, H. (2002). Smoke and mirrors? Evaluating the use of reflective practice as a management learning technique [Working paper]. Retrieved from http://www.leeds.ac.uk/educol/documents/00002316.htm

Fierke, K. K. and Lepp, G.A. (2015). Documenting student engagement using an Intention/Reflection exercise during an advanced pharmacy practice experience. The International Education Journal: Comparative Perspectives, 14(3); 47-60.

Grant, A. M., Franklin, J. \& Langford, P. (2002). The self-reflection and insight scale: A new measure of private self-consciousness. Social Behavior and Personality, 30(8), 821-835.

Kouzes, J. M. \& Posner, B. Z. (1995). The leadership challenge: How to keep getting extraordinary things done in organizations. San Francisco, CA: Jossey-Bass Publishers.

Kouzes, J. M. \& Posner, B. Z. (2008). The student leadership challenge. San Francisco, CA: John Wiley \& Sons, Inc.

Lussier, R., \& Achua, C. (2007). Leadership: Theory, Application, \& Skill Development. Thomson SouthWestern.

Mezirow, J. (1991). Transformative dimensions of adult learning. San Francisco: Jossey-Bass.

N'Vivo qualitative data analysis Software; QSR International Pty Ltd. Version 11, 2016.

National Center for Education Statistics. (2002). Teaching undergraduates in U.S. postsecondary institutions: Fall 1998 (NCES 2002-209), by X. Chen. Project Officer: L. J. Zimbler. U.S. Department of Education, Washington, DC: 2002.

Paavola, S. \& Hakkarainen, K. (2005). The Knowledge Creation Metaphor - An Emergent Epistemological Approach to Learning. Science \& Education, 14, 535-557. 10.1007/s11191-004-5157-0.

Roberts, A. \& Yoell, H. (2009). Reflectors, converts and the disengaged: A study of undergraduate architecture students' perceptions of undertaking learning journals. Journal for Education in the Built Environment, 4(2), 74-93.

Schön, D. (1983). The reflective practitioner. San Francisco: Jossey-Bass.

Senge, P. M. (1990). The fifth discipline: The art and practice of the learning organization. New York: Currency, Doubleday. 


\section{References}

Senge, P. M. (1994). The fifth discipline fieldbook: Strategies and tools for building a learning organization. New York: Currency, Doubleday.

Piaget, J. (1969). The mechanisms of perception (G. N. Seagrim, Trans.). New York: Basic Books, Inc. (Original work published 1961)

von Glasersfeld, E. (1984). An introduction to radical constructivism. In P. Watzlawick, The Invented Reality, (pp.17-40). New York: W.W. Norton \& Company.

Williams, R. M., \& Wessel, J. (2004). Reflective journal writing to obtain student feedback about their learning during the study of chronic musculoskeletal conditions. Journal of Allied Health, 33(1), 17-23.

Uygur J et al. (2019). A Best Evidence in Medical Education systematic review to determine the most effective teaching methods that develop reflection in medical students: BEME Guide No. 51. Medical Teacher, 41(1), 3-16.

Zimmerman, B. J. ( 2001). Theories of self-regulated learning and academic achievement: An overview and analysis. In B. J. Zimmerman \& D. H. Schunk (Eds.), Self - regulated learning and academic achievement (2nd ed. pp. 1-38). Hillsdale, NJ : Erlbaum . 